\title{
Existing Housing Management Practices Followed by Rural Dairy Animal Owners in Sabar Dairy Milk Shed of Gujarat, India
}

\author{
Praveen Pilaniya $^{1}$, P.M. Desai ${ }^{2}$ and Anil Mordia ${ }^{3 *}$
}

${ }^{I}$ Division of Livestock Production Management, Postgraduate Institute of Veterinary

Education and Research Kamdhenu University, Gandhinagar, Gujarat-382010, India

${ }^{2}$ Adjacent Faculty of Kamdhenu University, Gandhinagar, Gujarat-382010, India

${ }^{3}$ Livestock Research Station, Dag, Jhalawar, Rajasthan (RAJUVAS, Bikaner)-326514, India

*Corresponding author

\section{Key words \\ Dairy animals, Housing, Management, Practices, Animal owners and Gujarat \\ Article Info \\ Accepted: \\ 10 July 2018 \\ Available Online: \\ 10 August 2018}

\section{A B S T R A C T}

The study on status of housing practices followed by the dairy owners in Gujarat was conducted in Sabarkantha districts. The data were collected from randomly selected 150 dairy animal owners through personal interview using pre-tested structured schedule from three clusters (Ider, Prantij and Himmatnagar) was selected at randomly. The study revealed that majority of respondents $(52.66 \%)$ provided of the respondents kept their animals in pucca houses, whereas 36.66 per cent kept in kuccha type house of which 48.66 per cent animal sheds were nearby their dwellings. About 39.33 per cent of respondents had pucca floor in an animal shed. About 39.33 per cent of respondents had single roof shed. The roof made by galvanized iron sheet $(50.00 \%)$ was prevalent in the study area. The majority $(76.00 \%)$ of the respondents prepared wall of the shed from brick and lime/cement. 100 per cent respondents provided manger to their animal and a large number of respondents had pucca manger (68.00\%). 68.66 per cent of the respondents had constructed water trough in an animal shed. The majority $(64.00 \%)$ of dairy animal owners used bedding material for the pregnant animal. Mostly 70.00 per cent respondents had a proper light provision in an animal shed, pucca drainage facility for urine drain $(42.00 \%)$ and $70.66 \%$ respondents were aware of protecting their animals against inclement weather/climatic conditions.

\section{Introduction}

Livestock rearing is an integral part of agriculture in India as well as in many developing countries since centuries. The Indian dairy industry has made a remarkable progress in the last three decades with unprecedented growth in milk production. Cattle and buffalo play a major role in the Indian economy by producing milk which is the largest agricultural commodity in India. Gujarat is a very important state in milk production and marketing in India on a cooperative dairy system basis. This credit was achieved owing to the development of a wide network of a co-operative dairy system based on Anand pattern. Gujarat has around 5.23 per cent of cattle and 9.55 per cent of buffalo population of the country (Anonymous, 2014b). It contributed around 10.3 million 
tonnes (7.80 per cent) of milk to the total milk pool of India and per capita, milk availability was 476 gm/day during the year 2012-13 (Anonymous, 2014a).

Production potential of livestock depends mostly on the management practices under which they are reared and these practices vary significantly across various agro ecological regions due to many factors. Understanding of livestock management practices followed by farmers in a region is necessary to identify the strengths and weaknesses of the rearing systems and to formulate suitable intervention policies (Gupta et al., 2008). Each component of management practices interacts either independently or in combination to affect the productivity of the livestock. Almost all the farmers did not keep their animals at a single place throughout the year or even for a whole day and night. Provision of proper housing facilities to the animals not only reduces the energy wastage in maintaining thermo neutral zone but also provides good hygienic conditions, reduces the incidence of diseases, protects them from predators and provides better working conditions to the farmers. Therefore it is imperative to ascertain the scientific housing management practices of dairy animals followed by dairy animal owners under village conditions so that needbased extension programmed may be launched to make them aware to increase their knowledge and the adoption of scientific housing management practices for dairy animals.

\section{Materials and Methods}

In the present study information was collected by arrangement of field survey from Sabarkantha district of North Gujarat. Sabarkantha district possesses 8 Talukas out of which 3 Clusters (Ider, Prantij and Himmatnagar) were randomly selected. From each selected clusters 5 villages having functional primary milk producer's cooperative societies were selected at randomly. Ten dairy animal owners from each village were randomly selected making a total of 150 respondents. While selecting respondents due care was taken to ensure that they were evenly distributed in the village and truly represented animal management practices prevailing in the study area.

The selected farmers were interviewed and the desired information was collected regarding housing management practices adopted by them for dairy animals with the help of predesigned and pre-tested questionnaire. To analyze the collected information, several basis statistical tools and methods were used. The following statistical treatments were used for interpretation of data. Tentatively it has been planned to apply frequency distribution, percentage and chi-square test. The following formula was used to calculate chi-square value. Therefore, significance among the different classes will be tested with chisquares test (Snedecor and Cochran, 1994).

$\chi^{2}=\sum=\left[\frac{(\mathrm{O}-\mathrm{E}) 2}{\mathrm{E}}\right]$

Where,

$\mathrm{O}=$ Observed Frequencies in each animal group.

$\mathrm{E}=$ Expected Frequencies in each animal group.

\section{Results and Discussion}

The findings indicated that majority $(52.66 \%)$ of the respondents kept their animals in pucca housing system, whereas 36.34 per cent of the respondents provided kuccha type of houses and 10.66 per cent respondents had an open type of housing to their dairy animals. The results are highly significant $(\mathrm{P}<0.01)$. In 
Himmatnagar clusters (64.00\%) of respondents kept their animals in pucca housing system followed by Prantij (62.00\%) clusters also followed pucca housing system and in Ider clusters 48.00 per cent respondents followed kuccha housing system. The study was in contradiction to findings of Bainwad et al., (2007) observed that 77.50 per cent of the respondents provided kuccha shed and only 22.50 per cent provided pucca sheds. Ahiwar et al., (2009) also observed in rural areas significantly higher number $(59.33 \%)$ of farmers having mud houses and in urban areas 68.00 per cent of farmers had pucca houses.

It was observed that 27.34, 48.66 and 24.00 per cent of the respondents kept their animals attached to a human dwelling, nearby their dwelling house and in the field of farmers, respectively. Most of the respondents preferred to keep their animals in close proximity of house so that they can observe them more frequently. The findings of present study were in agreement with findings of Gupta et al., (2008) reported that 86.00 per cent of households provided separate stall within or outside the human dwelling and 13.90 per cent, were unable to provide separate housing facility to their bovines. It was found that half $(49.34 \%)$ of the respondents followed head to head system of animal housing, tail to tail (29.34\%) and single row type of housing system (21.34\%), respectively. The results are significant $(\mathrm{P}<0.05)$. These findings are not at par with the findings of Ahiwar et al., (2009) and Sabapara et al., (2015). Former reported that majority $(87.67 \%)$ of the respondents in the area of the study had single row.

The results was observed that 39.36 per cent respondents had pucca (cement and concrete) floor in their dairy animal shed, while earthen floors $(31.33 \%)$, brick paved $(13.34 \%)$, rubber mat with concrete floor (13.34\%) and stone paved $(2.66 \%)$, respectively. It is generally found that pucca floor was found to be better than kuccha floor for animals to keep them free from worm problems and also from the hygienic point of view in the study area. The respondents following kuccha floors showed unawareness about these problems. They believe pucca floors are cheap and comfortable to animals. The finding of present study were in agreement with findings of Modi (2003) in Sabarkantha district of North Gujarat who found that most $(82.00 \%)$ of the animal houses had pucca floors. These findings are contradictory to the earlier reports of Bainwad et al., (2007), Sabapara et al., (2010a), Varaprasad et al., (2013) and kishore et al., (2013).

It was observed that majority $(58.00 \%)$ of the respondents used galvanized iron sheet type roof, while 34.00, 11.34 and 4.66 per cent of respondents used asbestos sheet, thatch roofing the shed and no roof/tree shed, respectively in the study area. These finding are in agreement with Sabapara et al., (2015) observed that 33.67, 31.33, 22.33 and 12.67 per cent of respondents used asbestos sheets, thatched materials, galvanized iron sheets and tiles as roofing material in their animals sheds, respectively. The present study is in contradiction to findings of Divekar and Saiyed (2010) revealed that majority $(94.00 \%)$ of Gir owners did not provide any roofing to their animals and kept them in open or under the tree shade while, 6.00 per cent owners used asbestos or galvanized sheets as roofing materials for their animal sheds. The data regarding the features of roof revealed that 39.33 per cent of the respondents possessed single slope type of roof in the study area. These findings are in agreement with that of Garg et al., (2005) and Kumar et al., (2006). Their results were very similar to each other wherein 58.50 per cent of the respondents had single slope roof of shed followed by flat $(32.50 \%)$ and double slope $(9.00 \%)$ roof of shed (Table 1). 
Table.1 Distribution of the dairy animal owners according to housing practices

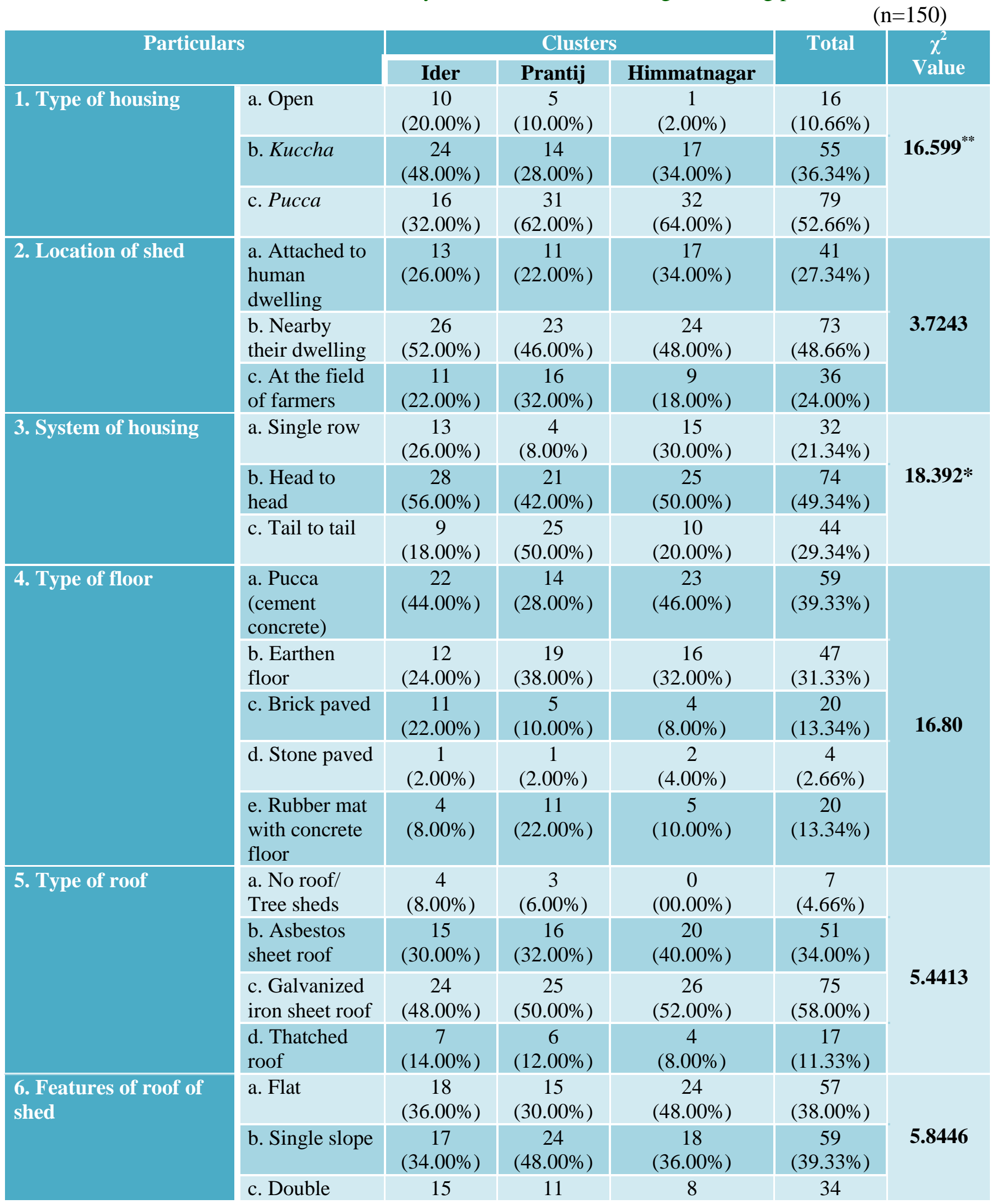




\begin{tabular}{|c|c|c|c|c|c|c|}
\hline & slope & $(30.00 \%)$ & $(22.00 \%)$ & $(16.00 \%)$ & $(22.66 \%)$ & \\
\hline \multirow[t]{4}{*}{$\begin{array}{l}\text { 7. Materials used in } \\
\text { walls }\end{array}$} & a. Thatch & $\begin{array}{c}5 \\
(10.00 \%)\end{array}$ & $\begin{array}{c}2 \\
(4.00 \%)\end{array}$ & $\begin{array}{c}1 \\
(2.00 \%)\end{array}$ & $\begin{array}{c}8 \\
(5.33 \%)\end{array}$ & \multirow{4}{*}{9.4371} \\
\hline & $\begin{array}{l}\text { b. Brick and } \\
\text { lime/cement }\end{array}$ & $\begin{array}{c}40 \\
(80.00 \%)\end{array}$ & $\begin{array}{c}34 \\
(68.00 \%)\end{array}$ & $\begin{array}{c}40 \\
(80.00 \%)\end{array}$ & $\begin{array}{c}114 \\
(76.00 \%)\end{array}$ & \\
\hline & $\begin{array}{l}\text { c. Brick in } \\
\text { mud }\end{array}$ & $\begin{array}{c}5 \\
(10.00 \%)\end{array}$ & $\begin{array}{c}13 \\
(26.00 \%)\end{array}$ & $\begin{array}{c}9 \\
(18.00 \%)\end{array}$ & $\begin{array}{c}27 \\
(18.00 \%)\end{array}$ & \\
\hline & d. Wooden & $\begin{array}{c}0 \\
(00.00 \%)\end{array}$ & $\begin{array}{c}1 \\
(2.00 \%)\end{array}$ & $\begin{array}{c}0 \\
(00.00 \%)\end{array}$ & $\begin{array}{c}1 \\
(0.66 \%)\end{array}$ & \\
\hline \multirow[t]{3}{*}{ 8. Type of pillar/pole } & a. Wooden & $\begin{array}{c}8 \\
(16.00 \%)\end{array}$ & $\begin{array}{c}8 \\
(16.00 \%)\end{array}$ & $\begin{array}{c}2 \\
(4.00 \%)\end{array}$ & $\begin{array}{c}18 \\
(12.00 \%)\end{array}$ & \multirow{3}{*}{9.44} \\
\hline & b. Iron & $\begin{array}{c}26 \\
(52.00 \%)\end{array}$ & $\begin{array}{c}18 \\
(36.00 \%)\end{array}$ & $\begin{array}{c}31 \\
(62.00 \%)\end{array}$ & $\begin{array}{c}75 \\
(50.00 \%)\end{array}$ & \\
\hline & c. Cemented & $\begin{array}{c}16 \\
(32.00 \%)\end{array}$ & $\begin{array}{c}24 \\
(48.00 \%)\end{array}$ & $\begin{array}{c}17 \\
(34.00 \%)\end{array}$ & $\begin{array}{c}57 \\
(38.00 \%)\end{array}$ & \\
\hline \multirow[t]{2}{*}{ 9. Provision of manger } & a. Yes & $\begin{array}{c}50 \\
(100 \%)\end{array}$ & $\begin{array}{c}50 \\
(100 \%)\end{array}$ & $\begin{array}{c}50 \\
(100 \%)\end{array}$ & $\begin{array}{c}150 \\
(100 \%)\end{array}$ & \multirow[b]{2}{*}{-} \\
\hline & b. No & $\begin{array}{c}0 \\
(00.00 \%)\end{array}$ & $\begin{array}{c}0 \\
(00.00 \%)\end{array}$ & $\begin{array}{c}0 \\
(00.00 \%)\end{array}$ & $\begin{array}{c}0 \\
(00.00 \%)\end{array}$ & \\
\hline \multirow[t]{3}{*}{ 10. Type of manger } & $\begin{array}{l}\text { a. Wooden } \\
\text { assisted } \\
\text { temporary }\end{array}$ & $\begin{array}{c}6 \\
(12.00 \%)\end{array}$ & $\begin{array}{c}4 \\
(8.00 \%)\end{array}$ & $\begin{array}{c}3 \\
(6.00 \%)\end{array}$ & $\begin{array}{c}13 \\
(8.66 \%)\end{array}$ & \multirow[t]{3}{*}{2.0063} \\
\hline & $\begin{array}{l}\text { b. Pucca } \\
\text { manger }\end{array}$ & $\begin{array}{c}31 \\
(62.00 \%)\end{array}$ & $\begin{array}{c}34 \\
(68.00 \%)\end{array}$ & $\begin{array}{c}37 \\
(47.00 \%)\end{array}$ & $\begin{array}{c}102 \\
(68.00 \%)\end{array}$ & \\
\hline & $\begin{array}{l}\text { c. Flexible } \\
\text { cement pipe } \\
\text { manger }\end{array}$ & $\begin{array}{c}13 \\
(26.00 \%)\end{array}$ & $\begin{array}{c}12 \\
(26.00 \%)\end{array}$ & $\begin{array}{c}10 \\
(20.00 \%)\end{array}$ & $\begin{array}{c}35 \\
(23.34 \%)\end{array}$ & \\
\hline \multirow[t]{2}{*}{$\begin{array}{l}\text { 11. Provision of water } \\
\text { trough in shed }\end{array}$} & a. Yes & $\begin{array}{c}36 \\
(72.00 \%)\end{array}$ & $\begin{array}{c}35 \\
(70.00 \%)\end{array}$ & $\begin{array}{c}32 \\
(64.00 \%)\end{array}$ & $\begin{array}{c}103 \\
(68.66 \%)\end{array}$ & \multirow[t]{2}{*}{0.8056} \\
\hline & b. No & $\begin{array}{c}14 \\
(28.00 \%)\end{array}$ & $\begin{array}{c}15 \\
(30.00 \%)\end{array}$ & $\begin{array}{c}18 \\
(36.00 \%)\end{array}$ & $\begin{array}{c}47 \\
(31.34 \%)\end{array}$ & \\
\hline \multirow[t]{2}{*}{$\begin{array}{l}\text { 12. Provision of } \\
\text { bedding material for } \\
\text { pregnant animal }\end{array}$} & a. Yes & $\begin{array}{c}35 \\
(70.00 \%)\end{array}$ & $\begin{array}{c}29 \\
(58.00 \%)\end{array}$ & $\begin{array}{c}32 \\
(64.00 \%)\end{array}$ & $\begin{array}{c}96 \\
(64.00 \%)\end{array}$ & \multirow{2}{*}{1.5625} \\
\hline & b. No & $\begin{array}{c}15 \\
(30.00 \%)\end{array}$ & $\begin{array}{c}21 \\
(42.00 \%)\end{array}$ & $\begin{array}{c}18 \\
(36.00 \%)\end{array}$ & $\begin{array}{c}54 \\
(36.00 \%)\end{array}$ & \\
\hline \multirow{2}{*}{$\begin{array}{l}\text { 13. Provision of } \\
\text { adequate light in } \\
\text { animal shed }\end{array}$} & a. Yes & $\begin{array}{c}34 \\
(68.00 \%)\end{array}$ & $\begin{array}{c}36 \\
(72.00 \%)\end{array}$ & $\begin{array}{c}35 \\
(70.00 \%)\end{array}$ & $\begin{array}{c}105 \\
(70.00 \%)\end{array}$ & \multirow[b]{2}{*}{0.1905} \\
\hline & b. No & $\begin{array}{c}16 \\
(32.00 \%)\end{array}$ & $\begin{array}{c}14 \\
(28.00 \%)\end{array}$ & $\begin{array}{c}15 \\
(30.00 \%)\end{array}$ & $\begin{array}{c}45 \\
(30.00 \%)\end{array}$ & \\
\hline \multirow[t]{2}{*}{$\begin{array}{l}\text { 14. Provision of urine } \\
\text { drain }\end{array}$} & a. Pucca drain & $\begin{array}{c}18 \\
(36.00 \%)\end{array}$ & $\begin{array}{c}23 \\
(46.00 \%)\end{array}$ & $\begin{array}{c}22 \\
(44.00 \%)\end{array}$ & $\begin{array}{c}63 \\
(42.00 \%)\end{array}$ & \multirow[b]{2}{*}{1.1494} \\
\hline & $\begin{array}{l}\text { b. Soaked at } \\
\text { earthen floor }\end{array}$ & $\begin{array}{c}32 \\
(64.00 \%)\end{array}$ & $\begin{array}{c}27 \\
(54.00 \%)\end{array}$ & $\begin{array}{c}28 \\
(56.00 \%)\end{array}$ & $\begin{array}{c}87 \\
(58.00 \%)\end{array}$ & \\
\hline \multirow{2}{*}{$\begin{array}{l}\text { 15. Provision and } \\
\text { practice to protect } \\
\text { animal from extreme } \\
\text { weather }\end{array}$} & a. Yes & $\begin{array}{c}40 \\
(80.00 \%)\end{array}$ & $\begin{array}{c}33 \\
(66.00 \%)\end{array}$ & $\begin{array}{c}33 \\
(66.00 \%)\end{array}$ & $\begin{array}{c}106 \\
(70.66 \%)\end{array}$ & \multirow[b]{2}{*}{3.1518} \\
\hline & b. No & $\begin{array}{c}10 \\
(20.00 \%)\end{array}$ & $\begin{array}{c}17 \\
(34.00 \%)\end{array}$ & $\begin{array}{c}17 \\
(34.00 \%)\end{array}$ & $\begin{array}{c}44 \\
(29.34 \%)\end{array}$ & \\
\hline
\end{tabular}

$\%=$ Per cent, $*$ Significant at $5 \%$ level $(\mathrm{P}<0.05) * *$ Significant at $1 \%$ level $(\mathrm{P}<0.01)$ 
The result observed that 76.00 per cent respondents was used Brick and lime/cement material for construction of the walls in the animal shed. Whereas, brick in mud $(18.00 \%)$, thatch material $(5.34 \%)$ and wooden type wall $(0.66 \%)$ respectively in the study area. The choice of materials for the construction might have been depended on economic condition of the farmer, level of intensification and locally available materials and strength of house required. The results are contrary to the study of Sinha et al., (2009) and Kumar and Mishra (2011a) stated that majority of the animal houses had full walls in their study area because of prolonged cooler period. The 31.00 per cent of the respondents used brick and cement walls, 22.0 and 1.33 per cent of the respondents used thatch and brick in mud for the sheds, respectively. The present findings are in agreement with finding of Rathore et al., (2010a). They reported that 51.75 per cent of the respondents used brick and lime and 44.75 per cent used brick in mud to construct the walls of the animal houses.

The result found that half $(50.00 \%)$ of the respondents was used iron type poles, while used cemented poles to support the roof $(38.00 \%)$ and only 12.0 per cent of the respondents used wooden poles to support the roof. The reason behind the use of the iron pole is fact that cemented/RCC poles are more robust and durable than the wooden poles. The findings are in contradiction of findings of Divekar and Saiyed (2010) where in the majority (50.33 per cent) of the respondents used cemented/RCC poles, while, 49. 67 per cent used wooden poles to support the roofs.

The results revealed that 100 per cent respondents provided manger to their animals, but these findings are not in agreement with the findings of Sabapara et al., (2015). The outcome of their study was that 66.00 per cent of the respondents provided manger to their animals, while 34.00 per cent did not provide any type of manger to their animals. Modi (2003) stated that 75.00 per cent of the farmers had mangers for their animals. This is indicative of progress made from 75.00 to 100 per cent.

The present study revealed that most of the respondents had pucca manger (68.00\%), flexible cement pipe manger $(23.34 \%)$ and wooden manger $(8.66 \%)$ for the feeding of animals. This might be due to the awareness of dairy farmers regarding prevention of wastage of feeds and fodder. Sinha et al., (2009) reported that majority of feeding mangers were kuccha in rural areas. Sabapara et al., (2015) observed that 33.33 per cent of the respondents had pucca type of manger while, 25.33 and 7.33 per cent had wooden assisted manger and kuccha type manger of varying size and shape.

The results observed that majority $(68.66 \%)$ of respondents provided water trough in animal shed and 31.34 per cent of respondents provided water facility near animal shed in the study area. The results are not in agreement to the results of the study of Fogya (2017) revealed that only 14.00 per cent of the respondents provided water trough in animal shed and 86.00 per cent of the respondents did not provide water trough in animal shed. The results revealed that 64.00 per cent respondents was used some bedding material for pregnant animals and didn't use any bedding material for pregnant animals $(36.00 \%)$ in the study area. The present findings are closely similar to the earlier findings of Sinha et al., (2009) reported that in rural areas, 73.30 per cent farmers were using sugarcane leaves and 13.30 per cent were using straw as bedding material. Fogya (2017) also found that 50.00 per cent of the respondents provided bedding material to pregnant cows. 
The results observed that 70.00 per cent respondents was had provision of adequate light in animal shed in the study area. The similar findings were reported by Ahirwar et al., (2009) and Sabapara et al., (2015) in both the studies 89.00 per cent of the respondents had provision of sufficient light in the animal houses. Contrary to the present study, Rathore et al., (2010a) reported that very low i.e. about 18.33 per cent of respondents provided sufficient light in the animal houses of high altitude Kumaon Himalaya and Churu district of Rajasthan, respectively.

Only 42.00 per cent of animal sheds had provision of pucca drainage facility of urine while, remaining $(58.00 \%)$ had no drainage facility but urine soaked in earthen floor of animal sheds. This resulted in dampness and unsanitary conditions. It was observed that some farmers practiced changing soil bedding or location of animals frequently. The result is similar to that of Sabapara et al., (2015) revealed that 36.33 per cent of the animal sheds had provision of pucca drainage facility for urine while, remaining 63.67 per cent had no drainage facility. However the results are different from the findings reported by Modi (2003) stated that 82.0 per cent of respondents provided pucca drains.

Findings of the present study indicated that majority $(70.66 \%)$ of the respondents adopted some kind of measures to protect the animals from extreme weather/climatic conditions, while 29.33 per cent of the respondents did not follow this practice. It might be due to the awareness of the dairy farmers regarding ill effects of the extreme weather conditions on health and production of the dairy animals.

The results are lower to that of Sabapara et $a l$. , (2015) revealed that majority $(58.33 \%)$ of the respondents of Surat district adopted some kind of measures to protect the animals from extreme weather conditions, while 41.67 per cent of the respondents did not follow this practice. Contrary to the present findings Rathore and Kachwaha (2009) reported 9.25 per cent of the buffalo owners used electric fan/water cooler in buffalo sheds during the hot period. It can be concluded that majority $(52.66 \%)$ of the respondents kept their animals in pucca housing system and 36.34 per cent of the respondents provided kuccha type of houses. The results are highly significant $(\mathrm{P}<0.01)$. In case of animal sheds were nearby their dwellings (48.66\%), puсca floor in animal sheds (39.33\%) and 39.33 per cent of respondents had single roof shed. The roof made by galvanized iron sheet $(50.00 \%)$ was prevalent and prepared wall of the shed from brick and lime/cement (76.00\%). 100 per cent respondents provided manger to their animal, pucca manger $(68.00 \%)$, constructed water trough in an animal shed (68.66\%), used bedding material for the pregnant animal $(64.00 \%)$, adequate light provision in an animal shed $(70.00 \%)$, pucca drainage facility for urine drain $(42.00 \%)$ and majority $(70.66 \%)$ of the respondents were aware of protecting their animals against extreme weather/climatic conditions in the study area.

\section{References}

Ahiwar, R. R., Nanavati, S. and Nayak, N. K. (2009). Studies on housing management of buffaloes under rural and urban areas of Indore district of Madhya Pradesh. Indian J. Field Vet., 5(3): 41-43.

Anonymous (2014a). Basic Animal Husbandry and Fisheries Statistics. AHS Series-15, Ministry of Agriculture Department of Animal Husbandry, Dairying and Fisheries Krishi Bhawan, New Delhi.

Anonymous (2014b). 19th Livestock census, 2012. Ministry of Agriculture Department of Animal Husbandry, Dairying and Fisheries, Government of India, Krishi Bhawan, New Delhi.

Bainwad, D. V., Deshmukh, B. R., Thombre, B. M. and Chauhan, D. S. (2007). Feeding 
and management practices adopted by buffalo farmers under watershed area. Indian J. Anim. Res., 41(1): 68-70.

Divekar, B. S. and Saiyed, L. H. (2010). Housing and breeding practices followed by professional Gir cattle owners of Anand district. Indian J. Field Vet., 5(3): 9-12.

Fogya S. L. (2017) Study on cattle management practices adopted by dairy farmers in Jaipur district of Rajasthan. M. Sc. Thesis. Sri Karan Narendra Agriculture University, Jobner.

Garg, M.K., Jain, L.S. and Chaudhary, J.L. (2005) Studies on housing, feeding and milking management practices of dairy cattle in Baran district of Rajasthan. Indian J. Dairy Sci. 58(2): 123-128.

Gupta, D.C., Suresh, A. and Mann, J.S. (2008) Management practices and productivity status of cattle and buffaloes in Rajasthan. Indian J. Anim. Sci., 78(7): 769-774.

Kishore, K., Mahender, M. and Harikrishna, C. (2013). A Study on buffalo management practices in Khammam district of Andhra Pradesh. Buffalo Bulletin. 32(2): 97-107.

Kumar, S. and Mishra, B.K. (2011a). Existing feeding and housing management practices followed by dairy producers in Tehri Garhwal district of Uttarakhand. Indian J. Anim. Prod. Mgmt., 27(3-4): 159-162.

Kumar, U., Mehla, R.K., Chandra, R. and Roy, B. (2006) Studies on manage mental practices followed by the traditional owners of Sahiwal cows in Punjab. Indian J. Dairy Sci. 59(2): 100-105.

Modi, R. J. (2003). Study of dairy animal management practices in Sabarkantha district of North Gujarat. M. V. Sc. Thesis. Sardarkrushinagar Dantiwada
Agricultural

University,

Sardarkrushinagar.

Rathore, R.S. and Kachwaha, R.N. (2009). Studies on existing management practices followed by the Buffalo owners in Jhunjhunu district of Rajasthan. Indian J. Anim. Prod. Mgmt., 25(1-2): 8-11.

Rathore, R.S., Singh, R., Kachwaha, R. N. and Kumar, R. (2010a). Existing management practices followed by the cattle keepers in Churu district of Rajasthan. Indian Journal of Animal Sciences, 80(8): 798805.

Sabapara, G. P., Fulsoundar, A.B. and Kharadi, V. B. (2015). Existing housing management practices followed by rural dairy animal owners in Surat district of Gujarat. International Journal of Farm Sciences, 5(4): 299-308.

Sabapara, G.P., Desai, P.M., Kharadi, V.B., Saiyed, L.H. and Singh, R. R. (2010a). Housing and feeding management practices of dairy animals in the tribal area of South Gujarat. Indian J. Anim. Sci., 80(10): 1022-27.

Sinha, R.R.K., Dutt, T., Singh, R.R., Bhushan, B., Singh, M. and Kumar, S. (2009). Feeding and housing management practices of dairy animals in Bareilly district of Utter Pradesh. Indian Journal of Animal Sciences, 79(8): 829-833.

Snedecor, G.W. and Cochran, W.G. (1994). Statistical methods. Journal of Educational and Behavioral Statistics, 19(3): 304-307.

Varaprasad, A.R., Raghunandan, T., Kumar, M.K. and Prakash, M.G. (2013). Management practices of the farmers rearing Jersey x Sahiwal cows in Chittoor district of Andhra Pradesh. Indian $J$. Anim. Prod. Mgmt., 29(1-2): 33-36.

\section{How to cite this article:}

Praveen Pilaniya, P.M. Desai and Anil Mordia. 2018. Existing Housing Management Practices Followed by Rural Dairy Animal Owners in Sabar Dairy Milk Shed of Gujarat, India. Int.J.Curr.Microbiol.App.Sci. 7(08): 1642-1649. doi: https://doi.org/10.20546/ijcmas.2018.708.188 